\title{
Inputs and Process Factors Affecting the Quality of Training in Nekemte College of Teachers Education, Ethiopia
}

\author{
Tesfa Chala
}

Department of Education, Nekemte College of Teachers Education, Post Box No: 88, Nekemte, Ethiopia

\begin{tabular}{|c|c|}
\hline Abstract & Article Information \\
\hline \multirow{12}{*}{$\begin{array}{l}\text { The main purpose of this research was to find out the condition of inputs and process of } \\
\text { training in Nekemte College of Teachers Education. In order to meet the purpose, a } \\
\text { descriptive survey study method was employed. Total } 456 \text { trainees of pre-service regular third } \\
\text { year student teachers of the year } 2012 / 2013 \text { and } 67 \text { teacher educators of the same year were } \\
\text { selected as a sample. From } 120 \text { teachers of linkage schools, } 50 \%(60) \text { teachers were } \\
\text { selected by using simple random sampling method. For this, quantitative data were collected } \\
\text { and analysed by using descriptive statistical tools such as percentage and chi-square tests. } \\
\text { The result of the study shows that there were poor conditions of facilities and educational } \\
\text { material/ inputs. Processing them in the way that they can give benefit as it is desired was } \\
\text { not at good condition in the college. In addition to this, absence of internal organizational } \\
\text { services of the college, inadequacy of the instructors' assessment techniques and } \\
\text { ineffectiveness in use of different instructional methods were some of the problems that need } \\
\text { urgent solution. Some recommendations are forwarded as how to bring quality training in } \\
\text { Nekemte College of Teachers Education. Thus, while recruiting trainees, attention should be } \\
\text { given to their academic performance, use of inputs and processing them, different methods of } \\
\text { instruction and assessment, normal class size as the standard set by MoE are some of the } \\
\text { recommendations forwarded to be practiced in the college. }\end{array}$} & IStor \\
\hline & Received : 29 \\
\hline & ied \\
\hline & 4 \\
\hline & \\
\hline & \\
\hline & \\
\hline & \\
\hline & \\
\hline & \\
\hline & a \\
\hline & \\
\hline
\end{tabular}

\section{INTRODUCTION}

Quality education is the great issue of these days. Therefore, to bring quality education teachers training colleges have a greater responsibility than other organizations because the source of qualified teachers is training institutions. According to Teshome (2007), the expansion of education, training and research institutions with required standard and quality is essential to realize the national capacity building and overall sustainable development of Ethiopia.

The quality of an education system depends to a large extent on securing a fair number of well qualified and equipped, contented and updated teachers (Harvey, 1995). For creating effective teachers we need an effective and well equipped teachers training institution whose mission is to promote the professional growth of teachers through pre-service and in-service training programmes (Shukla, n.d.).

The entire emphasis of Nekemte College of Teachers Education (NCTE) is to prepare good, knowledgeable and trained teachers for primary schools. However, the college encounter many problems when providing training to student teachers for quality teaching profession.

The quality parameters like training facilities, good physical plant, competent teacher educators, quality student teacher, conducive environment for curricular instruction need to be considered as pre-requisites for any quality training. If these are not available, colleges of teachers education seem to be the most adversely affected in offering quality training. Observation through experience, and complaints from the stakeholders indicate that new teachers graduated from Nekemte College of Teachers Education have the problems of low teaching competences and mastery of subject matter in providing new knowledge to the students. The study also sought to find the problems in implementing quality training in Nekemte College of Teachers Education. The following research questions were raised. What where the factors that affect quality training? What input and process factors affect the quality of teachers training in Nekemte College of Teachers Education? and How does the input and process composition relate to quality training?

The general objective of this study was to assess the major factors that affect the quality of training in Nekemte College of Teachers Education, with respect to inputs and process. Specifically, the focus of the study was to:

1. Assess the contribution of inputs and process of factors in quality training in NCTE.

2. Identify the factors of inputs and process that have negative impact on quality training.

3. Investigate how input and process are related in quality training. 


\section{Tesfa Chala}

The study will show educational leaders how to improve trainings, academic and professional issues. In addition to this, the study will assist the college leaders by identifying the underlying problems in educational inputs that bring quality reduction in training and points out the gap in processing the overall activities in the college. It may also serve as starting point for further research in the area.

It is important to understand that a teacher is one of the most important human resources in school system that requires quality training. If we can insist on better prepared and more able teachers, teacher quality or the capacity of teacher in teaching profession will also rise. As a result student performance will be better.

Quality is a concept that lacks a common definition that could be applicable in all fields, for every phenomenon or any subject (Janne, 2006). There are as many theories of quality as there are different writers. These different views of quality are often confusing and contradictory (Amare, 2005). In this study, quality is assessed in the concept of training of teachers. Accordingly, quality is taken as transforming and preparing teachers for the teaching profession in ethical manner, which deals with the empowerment and enhancement of the student teachers to take control of themselves in the training process (UNICEF, 2000). The more the trainees can manage in the future working life with the help of the knowledge, the better experience and skills acquired in the college. The more the training college can equip the student teachers with special skills, the better knowledge and attitudes that enable them to teach effectively.

\section{Teacher Education and Preparation}

Today, with a great understanding of the function that education has to the society and to the country as whole, Ethiopia is striving to expand education at all levels with the intention to transform society through education. To this end, new goals of access, equity, quality and efficiency have been articulated at national level in Ethiopian education and training policy of 1994. Because teacher training institutes have the potential to bring change in quality (Fekede, 2009),the place where trained man power for teaching could be prepared is teacher training colleges and can play a critical role in preparing quality teachers through quality training. However, the teaching profession is currently facing several challenges: nature of students, advanced technology, economic problem and how people learn caused teacher training to re-examine the basic principles and methodologies of teacher preparation for quality training in colleges. Because of these factors on teacher quality and professional development, different policies are carried out in different countries to attract talented students to become teachers and retain talented teacher (George et al., 2000).

\section{Teacher Quality}

Teacher quality is an important school level factor influencing student learning and ultimately preparing children for their future as citizens. The preparation that a teacher makes before beginning his work in the classroom and his being resourceful for teaching makes a teacher quality. Academic and professional qualification, refresher courses or trainings and teacher experiences are the important qualities of a teacher (Mulu, 2012). Academic
Sci. Technol. Arts Res. J., July-Sep 2014, 3(3): 166-175

qualifications and knowledge of the subject matter, competencies and skills and the commitment of teacher have an impact on the teaching learning process (Govt. of Pakistan, National Education Policy 1998). Classroom instruction mostly depends upon the teacher quality. Therefore, it is very important in the teaching profession. Lack of sufficient arrangements for teachers training and refresher courses, lack of the subject matter knowledge by the educators in training colleges, lack of basic facilities and transport facility and minimum salary for educators lower the quality of training (Kazmi, 2005) which in turn lower the quality of a prospective teacher who would be graduated from the training institutions. Similarly, the less years of schooling, training programs with lack of master trainers, no stress on teaching practice, absence of monitoring system and accreditation body, and politicized appointments are the factors of low teachers quality (Memon, 2007). In general, the education system can be improved if the teacher quality is improved through training (Memon, 2007).

Academic qualification is a very important quality of a teacher. Academically qualified teacher has more authentic knowledge about the relevant subject than the academically less qualified teacher has. Another qualification, which is very important for teachers, is professional qualification, that is, the basic skills and abilities of the teaching learning process developed in a teacher through professional qualification by taking professional courses during the time of training for teaching profession. Likewise, professional qualification can be termed as the preparation for the teaching profession. Professional qualification is offered for teachers in Ethiopia in two ways i.e. in pre-service and inservice program.

\section{Theoretical and Conceptual Framework}

This research stressed on two variables namely educational inputs and process that can affect education/training quality in NCTE. The conceptual framework of the study is, presented and elaborated in the system view of education to improve quality training in perspectives of two indicators. These are the elements of inputs: student recruitment, staffing, teaching and learning strategy, trainees assessment polices, infrastructure and library resources and as the elements of process indicators- program coordination, trainees' assessment practices and coordination of college-based training.

\section{Factors that affect the Quality of Teacher Training}

Educators consider quality of teacher training results from the training process, job experiences, and continuous learning professional enhancement (Nguyen, 2008). However, the quality of teacher training is impacted by different factors: input, teacher student competencies, teacher standards and the quality of the teacher, education curriculum, training conditions, learning environment and infrastructure. This category includes material resources: textbooks, learning materials, classrooms, libraries, school facilities and human resources most importantly teachers. Quality of instructional process and outcome process that impact quality of training from how teachers and administrators use educational materials (Rob, 1996).

\section{Quality Indicators for Teacher Education}

The role of teachers in overhauling the educational system and improving the quality and standard of 


\section{Tesfa Chala}

education is very crucial. Teachers being one of the major quality inputs, to achieve UPE goals, more and better trained teachers are needed (EFA, 2005). Educators consider inputs, process and outcomes as quality indicators for teacher education. Outputs and outcomes related are to the objectives of goal set. The immediate objective of educational policies is to improve educational achievements such as tests, knowledge of graduates, etc. can be measure through output indicators. Better education serves, labour productivity, better health and enhanced capabilities of individuals could be referred to as outcomes. Even though these are the parameters used to measure quality education, for the case of this study the first two parameters (input and process) were used.

Input indicators measure the means or the resources employed to facilitate the satisfaction of needs and hence, reach development objectives. Teacher student competences, standards and teacher educators quality, training curriculum, training conditions, i.e teachinglearning, processes environment and infrastructures of the training institutions are some of the inputs used to indicate quality training (Rob, 1996). In an education system, input indicators focus on the human, financial and material resources that have been assembled and channelled into educational activities. Such resource inputs are used to organize the provision of educational services in order to create intermediate outputs such as classes and learning activities. As it was explained by UNESCO (2012), examples of education input indicators include budget allocated to education, pupil-teacher ratios, pupilclassroom ratios, percentage of pupils without textbooks, etc.

Educational process is how teachers and administrators use inputs to frame meaningful learning experience for students/trainees. Their work represents a key factor in ensuring quality institutions processes. Quality as process suggests that not only inputs or results but also the nature of the intra- institutional interaction of student teachers and educators and quality of the programme or system valued (Don, 1993). In an education system, process indicators show how the resource inputs discussed above have been utilized to deliver educational services. These indicators show what actually happen in the classroom and during teaching/learning processes. Students' attendance rate at school, average number of class hours they participate in official class hours, and the frequency of use of teaching/learning materials are some examples of process indicators.

\section{MATERIALS AND METHODS}

According to Bowerman and Oconnel (2003), the research method employed is determined by the research topic. The major purpose of this study is to assess inputs and process of factors affecting quality training in NCTE. Descriptive survey study was used both quantitatively and qualitatively. The qualitative data collection approach was employed in order to secure the reliability of information gathered by quantitative method. The descriptive survey design is appropriate because it helps to obtain information about the existing status of training in NCTE.

\section{Description of the Study Area}

The study was conducted at Nekemte College of Teachers Education (NCTE). It is found in East Wellega Zone of Oromia Regional State and located $330 \mathrm{~km}$, West
Sci. Technol. Arts Res. J., July-Sep 2014, 3(3): 166-175

Addis Ababa. As the researcher observed, in any of the Regional State teachers training colleges, there is no research conducted on quality training. Thus, the researcher preferred to select Nekemte College of Teachers Education for this study.

\section{Sample Size}

The sample of the study were 456 regular third year student teachers and 67 teacher educators, 1 Dean and 1 Vic-Dean, 4 Stream Heads of NCTE and 4 Practicum coordinators from the 4 linkage schools, and $50 \%$ of 120 , that is 60 respondents were taken from the linkage schoolteachers as a sample.

\section{Sampling Techniques}

The sampling technique for this study was purposive and systematic sampling methods. The reason why NCTE and linkage school in Nekemte town were purposely selected was to easily get data from the nearby college to the researcher work place. NCTE was giving training in 2012/2013 for 456 trainees of pre-service regular third year student teachers. For this study, all the 456 trainees were considered as the study subjects to describe the data because it is thought to be more reliable and for more of judgmental reason in making decisions with regard to the large sample. For the four linkage schoolteachers, appropriate systematic random sampling technique was used. Thus, form the population of 120 linkage school teachers to be more convenient a sample of $60(50 \%)$ of teachers was required for the study. Accordingly, the schools by their names and number of teachers in the school were as follows. Beke Jema, Burka Bekumsa, Dire Jato and Burka Jato have 34, 30 , 27 and 29 teachers respectively. To calculate sample to be considered from each school, $n_{i}=p_{i}(n / N)$ formula was used. Where, $n_{i}$ = sample selected from each school, $p_{i=}$ proportion of population from each school, $\mathrm{N}=$ the total population and $n=$ sample size. Then, $34(60 / 120)=17$, $30(60 / 120)=15,27(60 / 120)=13.5$ and $29(60 / 120)=14.5$. Accordingly, from Beke Jema 17 teachers, Burka Bekumsa 15 teachers, Dire Jato 13 teachers and Burk Jato 15 teachers, 60 teachers were selected respectively from the four schools as sample of the study.

\section{Data Collection Instruments}

The data required for the study were gathered using the following data collecting tools. To collect the quantitative data, closed ended questionnaires and some open-ended questionnaires, observation checklist and to collect qualitative data interview was used as a data collection instrument. The questions are closed ended and followed by few open-ended items to provide the respondents opportunity to write additional comments of their feelings about the condition of educational inputs and process for quality training offered by NCTE. Before the actual data collection, pilot test was conducted in small scale in one of the study groups to test and improve the instruments. The pilot test was used to test the suitability, clarity, relevance and reliability of each Items. For the reliability Cronbach alpha test was used and alpha results of all parts of questionnaires were above 0.87 . The questionnaire and interview were administered to five NCTE instructors selected by snowball sampling technique. Based on their comments advisor and feedback from the pilot test, ambiguous statements were eliminated and some items modified and improved. 


\section{Tesfa Chala}

In addition to the questionnaire, a semi- structured interview was administered, to Dean, Vic-dean and four Stream Heads in NCTE and from four linkage schoolteachers four focal teachers of practicum coordinators were taken for the interview. The availability of curriculum materials such as textbooks, module, manual, reference books, science laboratories, audio and visual materials and infrastructural facilities for the training programs were observed by using check list in order to make sure the validity and reliability of the data in the research.

\section{Procedure of Data Collection}

A total of 576 copies of questionnaires were prepared and distributed to 456 trainees, 60 instructors and 60 linkage schoolteachers. The questionnaires and interview were administered to research subjects who were not involved in the pilot test. For creating ease on the part of the trainee respondents, the data collection instruments were prepared first in English, and translated into Afan Oromo by Afan Oromo teachers and distributed.

\section{Methods of Data Analysis}

The data gathered through close-ended questionnaires were tabulated and described quantitatively. The analysis was made by employing the descriptive statistics through percentage technique, frequency counts and chi-square test to assess the
Sci. Technol. Arts Res. J., July-Sep 2014, 3(3): 166-175

variables explicated in all questions in accounting for the relationship between educators, trainees and linkage schoolteachers' perceptions toward inputs and process factors affecting quality of training and to determine the significance level of responses from the respondents at significance level of $\alpha=0.05$ in all the analysis. The other type of data were qualitative which were collected through interview. The data were analysed by coding and categorizing ideas and selecting the most common theme in which the positive and negative ideas suggested were identified. The data collected by observation were used to confirm the reliability and validity of questionnaires and interview data.

\section{RESULTS AND DISCUSSION}

The main factors considered were availability of instructional materials, educational facilities like class size, textbooks, libraries, laboratories, computers and teacher educators' qualification, experience etc. for the general training process in Nekemte College of Teachers Education. In this study the adequacy and accessibility of material inputs as important elements for training were considered and assessed using rating variables (adequately, moderately and inadequately available). As Rob (1996) explained input indicator measures the means or the resources employed to facilitate quality training.

Table 1: Respondents perceptions towards the availability of material input in NCTE.

\begin{tabular}{|c|c|c|c|c|c|c|c|c|c|}
\hline \multirow{3}{*}{ No } & \multirow{3}{*}{ Items } & \multirow{3}{*}{ Variables } & \multicolumn{4}{|c|}{ Respondents } & \multirow{3}{*}{ Total } & \multirow{3}{*}{$x^{2}$} & \multirow{3}{*}{$P$-value } \\
\hline & & & \multicolumn{2}{|c|}{ Educators } & \multicolumn{2}{|c|}{ Trainees } & & & \\
\hline & & & No & $\%$ & No & $\%$ & & & \\
\hline \multirow{4}{*}{1} & & Adequately available & 13 & 21.66 & 200 & 46.08 & 213 & \multirow{4}{*}{13.230} & \multirow{4}{*}{0.001} \\
\hline & Modules & Moderately available & 45 & 75.0 & 219 & 50.46 & 264 & & \\
\hline & & Inadequately available & 2 & 3.33 & 15 & 3.45 & 17 & & \\
\hline & & Total & 60 & & 434 & & 494 & & \\
\hline \multirow{4}{*}{2} & & Adequately available & 2 & 3.33 & 22 & 5.06 & 24 & \multirow{4}{*}{4.799} & \multirow{4}{*}{0.091} \\
\hline & Reference books & Moderately available & 13 & 21.66 & 150 & 34.56 & 163 & & \\
\hline & & Inadequately available & 45 & 74.99 & 262 & 60.36 & 307 & & \\
\hline & & Total & 60 & & 434 & & 494 & & \\
\hline \multirow{4}{*}{3} & & Adequately available & 3 & 5.0 & 15 & 3.45 & 18 & \multirow{4}{*}{2.332} & \multirow{4}{*}{0.506} \\
\hline & Handouts & Moderately available & 17 & 28.33 & 121 & 27.88 & 138 & & \\
\hline & & Inadequately available & 40 & 66.66 & 298 & 68.66 & 338 & & \\
\hline & & Total & 60 & & 434 & & 494 & & \\
\hline \multirow{4}{*}{4} & & Adequately available & - & - & - & - & - & \multirow{4}{*}{5.759} & \multirow{4}{*}{0.056} \\
\hline & Charts/diagrams & Moderately available & 5 & 8.33 & 91 & 20.96 & 96 & & \\
\hline & & Inadequately available & 55 & 91.66 & 343 & 79.02 & 398 & & \\
\hline & & Total & 60 & & 434 & & 494 & & \\
\hline \multirow{4}{*}{5} & & Adequately available & - & - & 40 & 9.21 & 40 & \multirow{4}{*}{59.927} & \multirow{4}{*}{0.000} \\
\hline & Chemicals & Moderately available & 12 & 20.0 & 267 & 61.52 & 279 & & \\
\hline & & Inadequately available & 48 & 79.99 & 127 & 29.25 & 175 & & \\
\hline & & Total & 60 & & 434 & & 494 & & \\
\hline \multirow{4}{*}{6} & & Adequately available & - & - & 34 & 7.83 & 34 & \multirow{4}{*}{7.473} & \multirow{4}{*}{0.024} \\
\hline & Equipment & Moderately available & 13 & 21.66 & 125 & 28.80 & 138 & & \\
\hline & & Inadequately available & 47 & 78.33 & 275 & 63.36 & 322 & & \\
\hline & & Total & 60 & & 434 & & 494 & & \\
\hline \multirow{4}{*}{7} & \multirow{4}{*}{ Different Models } & Adequately available & 1 & 1.66 & 5 & 1.15 & 6 & & \\
\hline & & Moderately available & 5 & 8.33 & 133 & 30.64 & 138 & & \\
\hline & & Inadequately available & 54 & 90.00 & 296 & 68.02 & 350 & 13043 & ค م००1 \\
\hline & & Total & 60 & & 434 & & $\begin{array}{c}494 \\
\mathrm{Df}=2\end{array}$ & 13.043 & 0.001 \\
\hline
\end{tabular}

Table 1 shows the perception of respondents on the availability of material inputs for training in NCTE. The chisquare value $x^{2}=13.230, P=0.001$ shows with $\mathrm{df}=2$ when $\alpha=0.05$ level there is significant difference in the response between educators and trainees for this item. During observation, it was confirmed that the inadequacy of modules is not serious.

Item 2 alternatives were given on the availability of reference books. Based on this, majority of the 


\section{Tesfa Chala}

respondents, 45(74.99\%) instructors and 262(60.36\%) trainees, indicated that reference books are inadequately available. The chi-square test results $x^{2}=4.799$, with $\mathrm{df}=2$, at $P=0.091$, at $\alpha=0.05$ significance level, implies that there is no significant difference between the responses of teacher educators and trainees on the availability of reference books. This was confirmed when library was observed for the study.

Item 3 of this table tries to show the response on handouts, indicated that handouts are inadequate. Observed, $x^{2}=2.332$, with $\mathrm{df}=2$ at value of $P=0.506$ at $\alpha=$ 0.05 significance level there is no significant difference between the responses of instructors and trainees. This indicates that there is a shortage of handouts as one of the training input. As it is indicated in Table 1 the chisquare results for most of the items shows that at $\alpha=0.05$ level of significance, there was no statistically significant
Sci. Technol. Arts Res. J., July-Sep 2014, 3(3): 166-175

difference between the respondent responses on the availability of material inputs in NCTE since the $P$-value is greater than 0.05 . As it can be seen from data in the table, most of the educational inputs are not adequate. Thus, these prevailing factors of poor quality training. Teshome (2004) also indicated that if the quality of libraries, laboratories and classrooms are below the minimum requirement in HIs (High institutions), these can affect quality of education.

Training service given in Nekemte College of Teachers Education by different Departments of the college were assessed. Rating scale 'Good', 'Satisfactory' and 'Poor' was used to assess to which extent service was given to process the training. Harvey (1995) states that service depends on input such as well-qualified staff, well stocked libraries, well-equipped laboratories and students with good entry qualifications.

Table 2: Adequacy of training services

\begin{tabular}{|c|c|c|c|c|c|c|c|c|c|}
\hline \multirow{3}{*}{ No } & \multirow{3}{*}{ Items } & \multirow{3}{*}{ Variables } & \multicolumn{4}{|c|}{ Respondents } & \multirow{3}{*}{ Total } & \multirow{3}{*}{$x^{2}$} & \multirow{3}{*}{$\underset{\text { Value }}{P-}$} \\
\hline & & & \multicolumn{2}{|c|}{ Educators } & \multicolumn{2}{|c|}{ Trainees } & & & \\
\hline & & & No & $\%$ & No & $\%$ & & & \\
\hline \multirow{4}{*}{1} & & Good & - & - & 31 & 7.14 & 31 & \multirow{4}{*}{5.030} & \multirow{4}{*}{0.081} \\
\hline & Library & Satisfactory & 1 & 1.66 & 13 & 2.99 & 14 & & \\
\hline & & Poor & 59 & 98.33 & 390 & 89.85 & 449 & & \\
\hline & & Total & 60 & & 434 & & 494 & & \\
\hline \multirow{4}{*}{2} & & Good & - & - & 30 & 6.91 & 30 & \multirow{4}{*}{4.431} & \\
\hline & Science Lab & Satisfactory & 7 & 11.66 & 45 & 10.36 & 52 & & \multirow{3}{*}{0.109} \\
\hline & & Poor & 53 & 88.32 & 359 & 82.71 & 412 & & \\
\hline & & Total & 60 & & 434 & & 494 & & \\
\hline \multirow{4}{*}{3} & & Good & - & - & 20 & 4.60 & 20 & \multirow{4}{*}{2.901} & \multirow{4}{*}{0.234} \\
\hline & Guidance and & Satisfactory & 11 & 18.33 & 79 & 18.20 & 90 & & \\
\hline & & Poor & 49 & 81.66 & 335 & 77.18 & 384 & & \\
\hline & & Total & 60 & & 434 & & 494 & & \\
\hline \multirow{4}{*}{4} & & Good & - & - & 19 & 4.37 & 19 & \multirow{4}{*}{3.398} & \multirow{4}{*}{0.183} \\
\hline & Health services & Satisfactory & 24 & 40.00 & 144 & 33.17 & 168 & & \\
\hline & & Poor & 36 & 60.00 & 271 & 62.44 & 307 & & \\
\hline & & Total & 60 & & 434 & & 494 & & \\
\hline \multirow{4}{*}{5} & & Good & 9 & 15.00 & 100 & 23.04 & 109 & & \multirow{4}{*}{0.369} \\
\hline & redagogical & Satisfactory & 6 & 10.00 & 41 & 9.44 & 47 & \multirow{3}{*}{1.994} & \\
\hline & & Poor & 45 & 75.00 & 293 & 67.51 & 338 & & \\
\hline & & Total & 60 & & 434 & & $\begin{array}{c}494 \\
\mathrm{Df}=2\end{array}$ & & \\
\hline
\end{tabular}

Table 2 depicts the adequacy of service given in Nekemte College of Teachers Education by different Departments of the college. Majority of the respondents responded that service given by NCTE library is poor. The chi-square result $x^{2}=5.030$, with $\mathrm{df}=2$ at $P=0.081$ shows that at $\alpha=0.05$ level of significance, indicate that there is no statistically significant difference between the instructors and trainees responses on the item. When condition in the college library is observed because of many factors, what was replied by this group of respondents was correct.

Item 2 in the same table depicts the condition of science laboratory. Majority of the two groups of respondents indicated that service given by science laboratory is poor. The chi-square test $x^{2}=4.431$, with $\mathrm{df}=2$ at $P=0.109$ shows that at $\alpha=.05$ level of significance there is no statistically significant difference between instructors and trainees responses given. When the internal organization of NCTE science laboratory was observed truly, what this group of respondents replied was true i.e. the science laboratory is at poor condition because the necessary chemicals and materials for this level are not available in the laboratory. The presence and utilization of laboratories were related to better achievement (Fuller, 1987). Similarly, in the same Table Item 3 shows that service given by guidance and counselling is poor. Observed, $x^{2}=2.901$ with $d f=2$ at value of $P=0.234$ at $\alpha=0.05$ level of significance there is no statistically significant difference in the responses given by the instructors and trainees. No full health service was given by the college clinic. As it was observed, the clinic had lack of man power and materials to give service with all its capacity. Observed, $x^{2}=3.398$ with $\mathrm{df}=2$ at value of $P=0.183$ at $\alpha=0.05$ level of significance there is no statistically significant difference between the responses given by the instructors and trainees. Service from pedagogical centre is poor and no service at all by this centre to support the training process in preparing teaching aids. In this regard, no significant difference was observed among the instructors and trainees from their responses $\left(\mathrm{X}^{2}=1.994\right.$ with $\mathrm{df}=2$ at $P$ value $=0.369$ at $\alpha=.05$ level of significance). Therefore, the overall results show that training facilities and material inputs are found to be inadequately available to give services in NCTE. With respect to this, (Kazmi, 2005), stated that lack of basic facilities lower the quality of training. 


\section{Tesfa Chala}

\section{The Impact of Entry Quality of Trainees}

Table 3 indicates the responses on the entry quality of trainees' and analyses whether it has impact on training or not and to measure 'yes'/'no' question was used. Low educational facilities and material inputs at lower grade
Sci. Technol. Arts Res. J., July-Sep 2014, 3(3): 166-175

affects the educational background of the students. As Kuh (2007) indicates it in Mulu, success in university/college education is strongly related to preuniversity/college academic preparation and achievement of students.

Table 3: Entry quality of trainees

\begin{tabular}{|c|c|c|c|c|c|c|c|c|c|}
\hline \multirow[t]{2}{*}{ Item } & \multirow[t]{2}{*}{ Responses } & \multicolumn{2}{|c|}{ Instructors } & \multicolumn{2}{|c|}{ Trainees } & \multicolumn{2}{|c|}{$\begin{array}{c}\text { Linkage School } \\
\text { Teachers }\end{array}$} & \multirow[t]{2}{*}{$x^{2}$} & \multirow{2}{*}{$\begin{array}{c}P- \\
\text { Value }\end{array}$} \\
\hline & & No & $\%$ & No & $\%$ & No & $\%$ & & \\
\hline \multirow{3}{*}{$\begin{array}{l}\text { Do you think that, poor } \\
\text { school background of the } \\
\text { trainees' have impact on } \\
\text { their trainings? }\end{array}$} & Yes & 45 & 75.0 & 279 & 64.28 & 34 & 60.71 & \multirow{2}{*}{3.189} & \multirow[t]{2}{*}{0.203} \\
\hline & No & 15 & 25.0 & 155 & 35.72 & 22 & 39.29 & & \\
\hline & Total & 60 & 100 & 434 & 100 & 56 & 100 & \multicolumn{2}{|c|}{$D f=2$} \\
\hline
\end{tabular}

It is indicated in Table 3 that majority of the respondents, replied poor school background of the trainees' has impact on trainings. The chi-square result, $x^{2}=3.189$ indicates with $\mathrm{df}=2$, at $P$ value of 0.203 when $\alpha=$ 0.05 significant level, the responses between instructors, trainees and linkage schoolteachers have no statistically significant difference. In addition to this, the open ended question, "In what way does it have an impact?" Confirmed by most of respondents, the impact is affecting trainees academic achievement in college, less exposure for independent work and poor sense of competition among the trainees, is due to their poor school background was replied. In this respect, (Willams, 2000) revealed that, positive early experiences and interactions are vital in preparing quality learners/trainees.

Factors related to Organizational Services and Facilities Affecting Quality Training

Quality of facilities and services refers to the extent to which the accessible facilities are relatively up-to-date such as library collections, laboratories, equipment and course materials and the services are efficient enough to enhance quality of learning (Mulu, 2012). It was also observed that in the college library reference materials written in the language of instruction were not available. For example, the medium of instruction for training is Oromo language, but the reference books were only available in English language. For this, the observed $X^{2}=11.231$, with $\mathrm{df}=8$ at $P=0.189$ ) has no significant difference. As it was observed during the study, the college library service is not satisfactory. In addition to this, the library workers were not professionals that, they had no knowledge and skills as to how to manage and organize library. The results of the availability and effective utilization of library service is consistent with several studies that have shown strong correlation exists between school library and students' academic achievement (Williams, 2000). Low self confidence of the trainees is another factor that affects quality training as it is denoted by the respondents. In this respect (UNICEF, 2000) revealed that what trainees know and can do as well as the attitudes and expectations they have for themselves and their societies is another factor that affects quality training. For this, Item, the observed $X^{2}=46.854$, with $P=0.000$ statistically significant difference at $\alpha=0.05$ level in the responses between instructors, trainees and teachers was observed. The respondents have different view on the item.

Table 4: Condition of Course delivery in NCTE

\begin{tabular}{|c|c|c|c|c|c|c|c|c|c|c|}
\hline & & & \multicolumn{2}{|c|}{ Educators } & \multicolumn{2}{|c|}{ Trainees } & \multicolumn{2}{|c|}{ L.S.Teachers } & & \\
\hline & & & No & $\%$ & No & $\%$ & No & $\%$ & & \\
\hline \multirow{6}{*}{1} & & SA & 27 & 45.00 & 163 & 37.55 & 19 & 33.92 & 209 & \multirow{6}{*}{$\begin{array}{c}X^{2}=13.332 \\
P=0.101\end{array}$} \\
\hline & The components of the & A & 17 & 28.33 & 138 & 31.79 & 17 & 30.35 & 172 & \\
\hline & courses provided are more & UN & 8 & 13.33 & 103 & 23.73 & 9 & 16.07 & 120 & \\
\hline & theoretical & $\mathrm{D}$ & 6 & 10.00 & 16 & 3.68 & 6 & 10.71 & 28 & \\
\hline & & SD & 2 & 3.33 & 14 & 3.22 & 5 & 8.92 & 21 & \\
\hline & & Total & 60 & & 434 & & 56 & & 550 & \\
\hline \multirow{6}{*}{2} & & SA & 12 & 20.00 & 86 & 19.81 & 4 & 7.14 & 102 & \multirow{6}{*}{$\begin{array}{c}X^{2}=150.124 \\
P=0.000\end{array}$} \\
\hline & For the courses given, the & A & 13 & 21.66 & 93 & 21.42 & 7 & 12.50 & 113 & \\
\hline & duration of learning/training & UN & 5 & 8.33 & 105 & 24.19 & 13 & 23.21 & 123 & \\
\hline & hours is not sufficient & D & 21 & 35.00 & 90 & 20.73 & 32 & 57.14 & 143 & \\
\hline & & SD & 9 & 15.00 & 60 & 13.82 & - & - & 69 & \\
\hline & & Total & 60 & & 434 & & 56 & & 550 & \\
\hline \multirow{6}{*}{3} & & SA & 8 & 13.33 & 92 & 21.19 & 1 & 1.78 & 101 & \multirow{6}{*}{$\begin{aligned} X^{2} & =44.970 \\
P & =0.000\end{aligned}$} \\
\hline & The modes of the provision & A & 4 & 6.66 & 95 & 21.88 & 8 & 14.28 & 107 & \\
\hline & of the courses are most of & UN & 18 & 30.00 & 130 & 29.95 & 21 & 37.50 & 169 & \\
\hline & the time by lecture & $\mathrm{D}$ & 17 & 28.33 & 93 & 21.42 & 15 & 26.78 & 125 & \\
\hline & & SD & 13 & 21.66 & 24 & 5.52 & 11 & 19.64 & 48 & \\
\hline & & Total & 60 & & 434 & & 56 & & 550 & \\
\hline
\end{tabular}

Table 4 tries to show the responses on course delivery in NCTE. In this table Item 1 as we observe it, $27(45.00 \%)$ of instructors, $163(37.55 \%)$ of trainees and $19(33.92 \%)$ of the linkage schoolteachers respondents strongly agreed, on the point that the components of the courses delivered by NCTE are more theoretical. The observed, $x^{2}=13.332$ with $\mathrm{df}=8$, at calculated value of $P=0.101$ at $\alpha=0.05$ level of significance, no significant difference was observed between the instructors, trainees and linkage schoolteachers responses. In the same manner, as it can be seen from the table, majority of the respondents agreed that the components of the courses provided are 


\section{Tesfa Chala}

more theoretical. However, a balance between theory and practice provides multi-dimensional development for prospective teachers (Shukla, n.d). Item 3 of this table shows the modes of the provision of the courses are most of the time by lecture. The calculated results of $x^{2}=$ 44.972, with $\mathrm{df}=8$, at $P=0.000$, at $\alpha=0.05$ level of significance. Statistically there is a significant difference between the responses of instructors, trainees and teachers. From the data, majority of the respondents indicated uncertainty. This shows the provision of the
Sci. Technol. Arts Res. J., July-Sep 2014, 3(3): 166-175

courses are most of the time may be by lecture or by other methods.

Majority of the respondents responded that the trainees are less competent. From the responses of the respondents, it is possible to deduce that most instructors and linkage schoolteachers are in the intention of explaining the trainees as less competent. When their last two years results obtained in college is analysed from the documents, it confirms that they were less competent and the average mean from the table indicates this fact.

Table 5: Responses on academic competence of the trainees and adequacy of the instructors assessments techniques

\begin{tabular}{|c|c|c|c|c|c|c|c|c|c|c|}
\hline \multirow{3}{*}{ Item } & \multirow{3}{*}{ Responses } & \multicolumn{6}{|c|}{ Respondents } & \multirow{2}{*}{\multicolumn{2}{|c|}{ Total }} & \multirow{3}{*}{ Mean } \\
\hline & & \multicolumn{2}{|c|}{ Instructors } & \multicolumn{2}{|c|}{ Trainees } & \multicolumn{2}{|c|}{$\begin{array}{l}\text { L. school } \\
\text { teachers }\end{array}$} & & & \\
\hline & & No & $\%$ & No & $\%$ & No & $\%$ & No & $\%$ & \\
\hline \multirow{5}{*}{$\begin{array}{l}\text { 1. How would you } \\
\text { academically rate most } \\
\text { of the trainees }\end{array}$} & a. very competent & - & - & & & - & - & - & - & - \\
\hline & b. Competent & 22 & 36.66 & & & 13 & 23.21 & 35 & 30.17 & 29.93 \\
\hline & c. Less competent & 35 & 58.33 & & & 43 & 76.78 & 78 & 67.24 & 67.55 \\
\hline & d. Incompetent & 3 & 5.00 & & & - & & 3 & 2.58 & 2.50 \\
\hline & Total & 60 & & & & 56 & & 116 & 100 & \\
\hline \multirow{4}{*}{$\begin{array}{l}\text { 2. How do you rate the } \\
\text { adequacy of the } \\
\text { instructors' assessment } \\
\text { techniques }\end{array}$} & a. High & 5 & 8.33 & 79 & 18.20 & 4 & 7.14 & 88 & 16.00 & 11.22 \\
\hline & b. Intermediate & 51 & 85.00 & 284 & 65.43 & 44 & 78.57 & 379 & 68.90 & 76.33 \\
\hline & c. Low & 4 & 6.66 & 71 & 16.35 & 8 & 14.28 & 83 & 15.09 & 12.43 \\
\hline & Total & 60 & & 434 & & 56 & & 550 & 100 & \\
\hline \multirow{4}{*}{$\begin{array}{l}\text { 3. If your answer to } \\
\text { item } 2 \text { is low, what do } \\
\text { you think will be the } \\
\text { reason? }\end{array}$} & $\begin{array}{l}\text { i. Lack of pedagogical } \\
\text { knowledge and skill }\end{array}$ & 2 & 3.33 & 40 & 9.21 & 4 & 7.14 & 46 & 8.36 & 6.56 \\
\hline & ii. Irresponsibility & 2 & 3.33 & 14 & 3.22 & 2 & 3.57 & 18 & 3.27 & 3.37 \\
\hline & $\begin{array}{l}\text { iii. Lack of motivation/ } \\
\text { incentives }\end{array}$ & - & - & 17 & 3.91 & 2 & 3.57 & 19 & 3.45 & 2.49 \\
\hline & Total & 4 & & 71 & & 8 & & & & \\
\hline
\end{tabular}

Also the respondents explained the reason for low assessment techniques by the instructors in the same table of Item 3, that is, because of lack of pedagogical knowledge and skill responded by instructors, and linkage schoolteachers. This shows that majority of the instructors did not use fair techniques to assess the trainees because of lack of pedagogical knowledge and skill. This was the highest mean average obtained as it was indicated in the table. This can affect training of the student teachers and contribute to the declining of quality education /training. The highest quality of teachers/instructors, those most capable of helping their students/learner, has deep mastery of both pedagogy and their subject matter (Darling-Hammand, 1997).

Table 6: The adequacy of the instructors and responses on experience

\begin{tabular}{|c|c|c|c|c|c|c|c|c|}
\hline \multirow{3}{*}{ Item } & \multirow{3}{*}{ Responses } & \multicolumn{6}{|c|}{ Respondents } & \multirow{3}{*}{$\begin{array}{l}\mathrm{X}^{2} \text { and } \\
P \text {-value }\end{array}$} \\
\hline & & \multicolumn{2}{|c|}{ Instructors } & \multicolumn{2}{|c|}{ Trainees } & \multicolumn{2}{|c|}{ L. S. Teachers } & \\
\hline & & No & $\%$ & No & $\%$ & No & $\%$ & \\
\hline \multirow{3}{*}{$\begin{array}{l}\text { 1.Are there enough instructors in } \\
\text { your college in relation to the } \\
\text { number of trainees? }\end{array}$} & a. Yes & 19 & 31.66 & 102 & 23.50 & & & \multirow{3}{*}{$\begin{array}{c}X^{2}=1.900 \\
P=0.168 \\
D f=1\end{array}$} \\
\hline & b. No & 41 & 68.33 & 332 & 76.49 & & & \\
\hline & Total & 60 & & 434 & & & & \\
\hline \multirow{4}{*}{$\begin{array}{l}\text { 2. How experienced are the } \\
\text { instructors in your college? }\end{array}$} & a. Well experienced & 27 & 45.00 & 204 & 47.00 & & & \multirow{4}{*}{$\begin{array}{c}\mathrm{X}^{2=} 3.107 \\
P=0.212 \\
\mathrm{Df}=2\end{array}$} \\
\hline & b. Experienced & 33 & 55.00 & 211 & 48.61 & & & \\
\hline & c. Less experienced & & & 19 & 4.37 & & & \\
\hline & Total & 60 & & 434 & & & & \\
\hline \multirow{3}{*}{$\begin{array}{l}\text { 3. Does teaching experience have } \\
\text { a direct relationship with quality of } \\
\text { education/training? }\end{array}$} & a. Yes & 54 & 90.00 & 359 & 82.71 & 51 & 91.07 & \multirow{3}{*}{$\begin{array}{c}\mathrm{X}^{2}=4.245 \\
P=0.120 \\
\mathrm{Df}=2\end{array}$} \\
\hline & b. No & 6 & 10.00 & 75 & 17.28 & 5 & 8.92 & \\
\hline & Total & 60 & & 434 & & 56 & & \\
\hline 4. To what extent does knowledge & a.High & 50 & 83.33 & 257 & 59.21 & 34 & 60.71 & \multirow{4}{*}{$\begin{array}{c}X^{2}=39.239 \\
P=0.000 \\
D f=4\end{array}$} \\
\hline of pedagogy and experience have & b.Medium & 7 & 11.66 & 171 & 39.40 & 16 & 28.57 & \\
\hline \multirow[t]{2}{*}{ an impact on quality training? } & c.Low & 3 & 5.00 & 4 & 0.92 & 6 & 10.71 & \\
\hline & Total & 60 & & 434 & & 56 & & \\
\hline
\end{tabular}

Table 6 Item 1 indicates the responses on the number of instructors in relation to the number of trainees in NCTE. Accordingly, majority of the respondents responded that there are no enough instructors in relation to the number of trainees. As it is observed, in NCTE, the ratio of trainees to the instructors is under standard, which negatively affects the quality of training. In the same table Item 3, respondents' views wether teaching experience has a direct relationship with quality education/training or not is explained. Accordingly, it was responded that teaching experience have a direct relationship with quality education/training. On the other hand, from the same group of respondents, some stated that teaching experience has no direct relationship with quality education/training and this response has no literature base. In contrast a literature confirms that quality teaching 


\section{Tesfa Chala}

demands appropriate qualifications, professional competence i.e. capacity and experience (Mulu, 2012).

As it is shown In Table 6, the observed chi-square results for items 1,2 and 3 that is, $X^{2}=1.900, P=0.168, X^{2}$ $=3.107, P=0.212$ and $X^{2}=4.245$ with $P=0.120$ respectively for all the three items. Their $p$ - value is greater than $\alpha=.05$ level of significance. This shows there are no different responses between the instructors and trainees on the adequacy of the instructors and their experience of work.

In Table 6 of Item 4, the respondents of the three groups tried to rate to what extent knowledge of pedagogy
Sci. Technol. Arts Res. J., July-Sep 2014, 3(3): 166-175

and experience have an impact on quality training. Accordingly, it was indicated that knowledge of pedagogy has high impact on quality training. As majority of the respondents having knowledge of pedagogy and experience indicates it has positive impact on quality training process. With respect to this, the highest quality of teachers/instructors, those most capable of helping their students/learner, has deep mastery of both pedagogy and their subject matter (Darling-Hammand, 1997). The observed, $x^{2}=39.239$ with, $P=0.000$ at $\alpha=.05$ level of significance, significant responses were observed between instructors, trainees and teachers.

Table 7: Method of utilizing training methods and its frequency as observed by trainees and instructor

\begin{tabular}{|c|c|c|c|c|c|c|c|c|c|c|}
\hline \multirow{3}{*}{ No } & \multirow{3}{*}{ Instructional Methods } & \multirow{3}{*}{ Respondents } & \multicolumn{8}{|c|}{ Responses and Frequency Observed } \\
\hline & & & \multicolumn{2}{|c|}{ Always } & \multicolumn{2}{|c|}{ Sometimes } & \multicolumn{2}{|c|}{ Not at All } & \multicolumn{2}{|c|}{ Total } \\
\hline & & & No & $\%$ & No & $\%$ & No & $\%$ & No & $\%$ \\
\hline \multirow{2}{*}{1} & \multirow{2}{*}{ Demonstration } & Instructors & 9 & 15.00 & 46 & 76.66 & 5 & 8.33 & 60 & 100 \\
\hline & & Trainees & 58 & 13.36 & 310 & 71.42 & 66 & 15.20 & 434 & 100 \\
\hline \multirow{2}{*}{2} & \multirow{2}{*}{ Lecture method } & Instructors & 35 & 58.33 & 15 & 25.00 & 10 & 16.66 & 60 & 100 \\
\hline & & Trainees & 211 & 48.84 & 198 & 45.62 & 24 & 5.52 & 434 & 100 \\
\hline \multirow{2}{*}{3} & \multirow{2}{*}{ Group discussion } & Instructors & 42 & 70.00 & 13 & 21.66 & 5 & 8.33 & 60 & 100 \\
\hline & & Trainees & 240 & 55.29 & 144 & 33.17 & 50 & 11.52 & 434 & 100 \\
\hline \multirow{2}{*}{4} & \multirow{2}{*}{ Role play } & Instructors & 13 & 21.66 & 35 & 58.33 & 12 & 20 & 60 & 100 \\
\hline & & Trainees & 120 & 27.64 & 222 & 51.15 & 92 & 21.19 & 434 & 100 \\
\hline \multirow{2}{*}{5} & \multirow{2}{*}{ Presentation method } & Instructors & 17 & 28.33 & 27 & 45.00 & 16 & 26.66 & 60 & 100 \\
\hline & & Trainees & 142 & 32.71 & 270 & 62.21 & 22 & 5.04 & 434 & 100 \\
\hline \multirow{2}{*}{6} & \multirow{2}{*}{ Field trip/visit } & Instructors & - & - & 9 & 15.00 & 51 & 85.00 & 60 & 100 \\
\hline & & Trainees & 34 & 7.83 & 248 & 57.14 & 152 & 35.02 & 434 & 100 \\
\hline \multirow{2}{*}{7} & \multirow{2}{*}{ Assignment } & Instructors & 57 & 95.00 & 3 & 5.00 & - & - & 60 & 100 \\
\hline & & Trainees & 246 & 56.68 & 182 & 7.89 & 6 & 1.38 & 434 & 100 \\
\hline \multirow{3}{*}{8} & \multirow{3}{*}{ Project } & Instructors & 16 & 26.66 & 33 & 55.00 & 11 & 18.33 & 60 & 100 \\
\hline & & Trainees & 60 & 13.82 & 290 & 66.82 & 84 & 19.35 & 434 & 100 \\
\hline & & Average mean & & 35.39 & & 43.56 & & 18.59 & & \\
\hline
\end{tabular}

Table 7 depicts the method of utilization of training methods as viewed by the two groups of respondents and qualitative scale: 'always', 'sometimes 'and 'not at all' was used to measure the responses. In the items listed in the table, most of the respondents i.e. $76.66 \%$ of instructors and $71.42 \%$ of trainees replied that demonstration is administered sometimes. On the other hand, $58.33 \%$ of instructors and $48.84 \%$ of trainees responded that lecture methods are utilized always in the teaching/training method. Regarding group discussion both groups, i.e. $70 \%$ instructors and $55.29 \%$ of trainees, replied that it is being administered always. Considering role-play method, $58.33 \%$ of instructors and $51.15 \%$ of trainees responded that it was utilized some times in the college as training method. In the same table, presentation methods are used some times according to $58.33 \%$ of the instructors and $62.21 \%$ of trainees' response. On the other hand, $85 \%$ of the instructors replied that field trips are not used at all while $57.14 \%$ of trainees replied that field trip/visit is used some times. In the same item, $95 \%$ of instructors and $56.68 \%$ of trainee responded that assignments are used always. Sometimes, project is used as means of training as indicated by $55 \%$ of instructors and $66.82 \%$ of trainees.

As it was observed from the responses of the respondents, the process or the correct method of utilizing, teaching/ training methods in NCTE is not conducted. Majority of the teacher educators were using lecture methods regularly. The average mean of the responses i.e. $43.56 \%$ indicates that most of the methods were utilized sometimes. This means other methods of training are utilized rarely. This leads to instructor dominated class in which the student teachers are passive participants of the training process. From this discussion, it is possible to conclude that quality of education/training is declining due to improper methods in training process. The methods teachers organize and use techniques of subject matter, teaching tools and teaching materials to meet teaching objectives determines quality of education/training (Asikhia, 2010).

Table 8 tries to depict causes that lead to the decline of quality education/training in NCTE. Item 1 of this table asks whether the three groups of respondents agree or disagree on the current decline of the status of quality of training in NCTE. Most of the respondents, $88.33 \%$ of instructors, $65.66 \%$ of trainees and $67.85 \%$ of teachers, from linkage school agree that the quality of training is deteriorating in NCTE. The average mean of the responses, 73.94\% confirms the response. During interviews, respondents also agree that the quality of training/education is declining due to different reasons.

In Item 2 of the same table, the respondents of the three groups tried to reason out why the quality of training is declining in NCTE. Depending on this instructors rate lack of reasonable standards for quality education is lack of material input like instructional facilities, textbooks and large class size second. However, trainees rank first and 
Table 8: Responses on the causes of decline of quality education/training

\begin{tabular}{|c|c|c|c|c|c|c|c|c|}
\hline \multirow{3}{*}{ Item } & \multirow{3}{*}{ Responses } & \multicolumn{7}{|c|}{ Respondents } \\
\hline & & \multicolumn{2}{|c|}{ Instructors } & \multicolumn{2}{|c|}{ Trainees } & \multicolumn{3}{|c|}{ L.S. Teachers } \\
\hline & & No & $\%$ & No & $\%$ & $\mathbf{N}$ & $\%$ & Mean\% \\
\hline \multirow{4}{*}{$\begin{array}{l}\text { 1. These days there is an assumption that quality of } \\
\text { education/training is declining. Do you agree with } \\
\text { this idea? } \\
\text { 2. If your answer to the above item is "agree" rank } \\
\text { order the most likely reasons why it is the case }\end{array}$} & a. $f$ & 53 & 88.33 & 285 & 65.66 & 38 & 67.85 & 73.94 \\
\hline & b. D & 5 & 8.33 & 109 & 25.11 & 9 & 16.07 & 16.50 \\
\hline & c. not decide & 2 & 3.33 & 40 & 9.21 & 9 & 16.07 & 5.53 \\
\hline & Total & 60 & & 434 & & 56 & & \\
\hline \multirow{3}{*}{$\begin{array}{l}\text { 1. Lack of reasonable standards for quality education } \\
\text { 2. Lack of instructors teaching experience } \\
\text { 3. Low qualification of instructors }\end{array}$} & & 51 & 85.00 & 170 & 39.17 & 50 & 89.28 & 71.15 \\
\hline & & 25 & 41.66 & 202 & 46.54 & 45 & 80.35 & \\
\hline & & 18 & 30.00 & 115 & 26.49 & 33 & 58.92 & 38.47 \\
\hline $\begin{array}{l}\text { 4. Lack of materials input like instructional facilities, } \\
\text { text books, crowded class size }\end{array}$ & & 49 & 81.66 & 228 & 52.53 & 53 & 4 & 76.27 \\
\hline \multirow{2}{*}{$\begin{array}{l}\text { 5. Lack of pedagogical training of instructors } \\
\text { 6. Incompetence of management of teacher training } \\
\text { college }\end{array}$} & & 35 & 58.33 & 167 & 38.47 & 38 & 67.85 & 54.88 \\
\hline & & 13 & 21.66 & 144 & 33.17 & 16 & 28.57 & 27.80 \\
\hline
\end{tabular}

second lack of material input like instructional facilities, textbooks, large class size and lack of instructors teaching experience respectively. On the other hand, linkage schoolteachers ranked first and second lack of material input like instructional facilities, textbooks, large class size and lack of reasonable standards for quality education. The third and fourth ranked by instructors and linkage schoolteachers were lack of pedagogical training of instructors and low qualification of instructors. Lastly, the instructors, trainees and teachers ranked incompetence of management of Teacher Training College at the end. As observed from the discussion, majority of the respondents i.e. instructors and linkage schoolteachers focused on lack of materials input like instructional facilities, textbooks, large class size, and lack of reasonable standards for quality education, while the trainees focused on lack of material input like instructional facilities, textbooks, crowded class size, lack of instructors teaching experience and lack of reasonable standards for quality education. This shows that there is a conceptual difference in rating the item. With respect to this, (Harver, 1995) stated that lack of material inputs and instructional facilities affect quality training.

From the average mean of the responses, the reasons ranked were first, lack of materials input like instructional facilities, textbooks, large class size; second, lack of reasonable standard for quality education, third, lack of instructors' teaching experience, fourth, lack of pedagogical training of instructors and low qualification of instructors and finally, incompetence of management of teachers training college were the reasons ordered by the respondents.

The interviews and the open-ended questions confirmed that in NCTE the quality of training has declined. As it was observed, the institute does not have sufficient instructional materials such as textbooks/ modules, sufficient number of computers, standardized laboratory workshops for science subjects training, different models, charts/diagrams, maps and globs. All these can lead to the deduction that the problem of NCTE in provision of quality training is manyfold and needs urgent measures to correct. The interview made with the college teacher instructors and department heads confirms that they also agree that quality of training is declining in NCTE this day. According to (Fuller, 1986), instructional materials (textbooks and other reading materials), building quality, library and laboratory significantly influence learner achievement. Likewise, Alexander and Simmons (1975) described that textbooks availability is an important indicator for performance of a learner.

\section{Perception on Class Size}

One of the factors affecting learning/training is class size. The observation attempted for this study confirms the number of trainees in a class is more than 50 in NCTE. This was also proved true from the college's records. Thus, the number of trainees in each class is more than the standard set by MoE which states that number of students/trainees in one class for tutor should not be more than 40 and for practical works such as science laboratory experiments should not exceed 30 . This had negative impact on the quality of training process. The larger the class size or the higher the students'- teacher ratio to teacher educators, the lower the learner achievement (Don, 1993).

The open-ended question dealt with the major problems that are causes for the deterioration of quality/education due to academic and management problems observed in NCTE. Majority of the respondents indicated that the main academic problems in NCTE are lack of material inputs and processing them in correct way, low academic background of the trainees, recruitment of students that scored low grades, trainees' interest, teachers work load, large class size and other problems. The interviewees also confirmed that these were the major academic problems and suggested that students with best result should be recruited, all necessary training inputs should be supplied by the college on time and must be used only for the correct purpose and teachers workload should be according to the charter of the college and the number of trainees in class should be minimized as the standard given by Ministry of Education.

Managerial problems that deteriorate quality education were indicated by respondents during the interview. Some of the problems were lack of academic freedom by teachers, lack of mutual understanding between instructors and management body, overloading instructors with routine and non-academic issues, discouraging instructors, rather than giving attention to training process (Memon, 2007), less tendency to allow instructors in managerial decisions, lack of transparency and closed information by administrative. The respondents also suggested that academic freedom and merit based promotion and rewards for instructors, participating in decision making, creating mutual understanding and friendship, participatory approaches and transparency and 


\section{Tesfa Chala}

high involvement in training process by the administrative management could help the college in assuring quality training.

\section{CONCLUSIONS}

The objective of higher education institutes is to provide education/training to assist in producing qualified human power for their country. Nekemte College of Teachers Education works for this objective. The College encounters many problems when providing training to student teachers for quality teaching profession. The concept of providing quality education/training is a core idea in provision of training for trainees. One of the findings regarding input shows, students scored below minimum point 2.0 can join Teachers Training College for training and be teachers after the completion of the training. From this, it can be concluded that academically less competent students have joined the college which as a result has an impact on the training process. The findings revealed that there are no significant differences between the responses observed, the instructors, trainees and linkage schoolteachers in entry quality of the trainees, accessibility of facilities and different departments service, qualification and competence of instructors. This shows that the training inputs and processes factors affected quality of training in NCTE.

The training process lacks using different training methods, which has implications to quality training as it is indicated by the findings. The training and assessment practices are also limited only to a few methods which obviously influence quality of training. The study revealed that NCTE administrative management involvement in the training process is not high. The study also showed that the college does not allow instructors and trainees to participate in academic decision making process. The condition can discourage instructors to give quality training. The findings indicated that there were academic and management problems that hinder provision of quality training in NCTE. Some interview respondents mentioned that the college management should seek urgent solutions for the problems in order to provide quality training. In Ethiopian context, Colleges of Teachers Education have purpose of preparing teachers for primary schools. To meet this purpose, while recruiting and selecting trainees, the college administration in collaboration with Oromia Educational Bureau should give attention to the students' academic performance in lower grades, concerns and abilities with good discipline that can make them be responsible teachers. Needs to improve inputs and process of training to attain quality outcome is also recommended.

\section{REFERENCES}

Alexander, L., and Simmons, J. (1975). The determinants of school Achievement in Developing Countries: The Educational Production Function (Staff Working Paper No.201). International Bank for Reconstruction and Development: World Bank, Washington, DC.

Amare Asegedom (2005). Freedom as Quality of Education. A Post-modern Perspective. IER-Flambeau 12(2): 1-21.

Asikhia, O.A. (2010). Students and teachers' Perception of the Causes of Poor Academic Performance in Ogun State Secondary School (Nigeria): Implications for Counselling for National Development. European Journal of Social Science 13(2): 229- 242.
Sci. Technol. Arts Res. J., July-Sep 2014, 3(3): 166-175

Bowerman, B.O. (2003). Business Statistics in Practices. $3^{\text {rd }}$ ed. McGraw-hi education company, Inc, New York.

Darling-Hammond, L. (1997). Doing What Matters Most: Investing in Quality Teaching. Kurtztown, Pennsylvania, National Commission on Teaching and America's Future. (http:/www.te. Columbia.edu/ teachcomm).

Don, A. (1993). Defining Educational Quality, University of Pittsburgh January 6, 1993.

EFA Global Monitoring Report (2005). Understanding education quality. The Dakar Framework for Action.

Fekede Tuli and Gemechis File (2009). Practicum experience in Teacher Education. Ethiopia. Journal Education and Science 5(1): 99.

George, J., Worrell, P., Rampersad, J., and Rampaul, B. (2000). Becoming a primary school teacher in Trindad and Tobago (Part 2, Teaching practice experience of Trainees).

Government of Ethiopia (1994). Education and Training Policy, Addis Ababa.

Government of Pakistan (1998). National Education Policy 1998-2010, Ministry of Education, Islamabad, Pakistan.

Harvey, L. (1994). Editorial. Quality in Education 1(1): 5-12.

Janne, P. (2006). Vadyba/Management. Nr. 2(11).

Kazmi, S.W. (2005). Role of Education in Globalization: A case for Pakistan. SAARC Journal of Human Resource Development 107: 90-107.

Memom, G.R. (2007). Education in Pakistan: The key Issues, Problems and The New Challenges, Development of Education, University of Karachi. Journal of Management and Social Sciences 3(1):47-55.

MoE. (1994). Educational and Training Policy. Addsis Ababa.

Muhammad, A. (2011). Impact of Teacher Quality on the Academic Achievements of students at secondary stage in Punjab (Pakista). European Journal of Social Sciences 19(1): 97-98.

Mulu Nega Kahsay (2012). Quality and Quality Assurance in Ethiopian Higher Education: Critical Issues and Practical Implications, April 2012.

Nguyen Thi Mg Loc (2008). Teacher training models in the world and suggestion of new Teacher training models in Vietnam, Report of the Priority Ministerial.

Rob, V. (1996). Educational Indicators: What's To Be Measured? Working Paper Series I-1 Washington D.C.

Shukla, R.P., (n.d.) A Study of Responses of Prospective Teachers on Existing Bachelor of Education Course.

Teshome Yizengaw. (2007). The Ethiopian Higher Education Creating Space for Reform. St. Mary's U.C printing press, Addis Ababa, Ethiopia.

Willams, J.D. (2000). Standards of Care: Instruments to Improve Children's Educational Outcomes in Latin America. Paper Presented at the "Year 2000 Conference of Early Development". Sponsored by the World Bank, Washington, D.C. April, 2000.

UNESCO (2012). EFA Global Monitoring Report 2005: Education for All-The Quality Imperative. Praise: UNESCO.

UNICEF (2000). Defining Quality in Education. A Paper presented by UNICEF at the meeting of the International Working Group on Education Florence, Italy. 